\title{
Alfred Flechtheim: Kunsthändler der Moderne, The Georg Kolbe Museum, Sensburger Allee 25, Charlottenburg, Berlin. Daily from 10:00 to 18:00 through 17 September
}

\author{
Jean Marie Carey
}

To cite this article: Jean Marie Carey (2017): Alfred Flechtheim: Kunsthändler der Moderne, The Georg Kolbe Museum, Sensburger Allee 25, Charlottenburg, Berlin. Daily from 10:00 to 18:00 through 17 September, Journal of Visual Art Practice, DOI: 10.1080/14702029.2017.1366691

To link to this article: http://dx.doi.org/10.1080/14702029.2017.1366691

Published online: 24 Aug 2017.

Submit your article to this journal $₫$

Q View related articles ¿

View Crossmark data $־$ 


\title{
Alfred Flechtheim: Kunsthändler der Moderne, The Georg Kolbe Museum, Sensburger Allee 25, Charlottenburg, Berlin. Daily from 10:00 to 18:00 through 17 September
}

\author{
Sprung in den Raum Skulpturen bei Alfred Flechtheim, by Arie Hartog, Helen \\ Shiner et al., edited by Ottfried Dascher, Wädenswil, Switzerland, Nimbus Books, 2017
}

Alfred Flechtheim: Kunsthändler der Moderne is the first exhibition in Berlin dedicated to one of the avant-garde's most beloved enthusiasts. Flechtheim - a collector, dealer and publisher owned a range of avant-garde art, but the emphasis of this exhibition is on his sculpture. The curator, Dr Julia Wallner, has arranged this exhibition as a historical collection, rather than confronting the battle that has raged over the nature, then the fate of entartete Kunst.

It is in fact precisely the issue of Raubkunst - art looted by the Nazis - that has returned Flechtheim to mainstream prominence. Flechtheim's heirs have filed a lawsuit against Bavaria, and by extension several German and US museums, over paintings by Max Beckmann, George Grosz and others seized from his galleries in Germany and Austria after Flechtheim was forced to close them and flee to London in 1933 (Bowley 2016). Though some of the research articles attendant to the exhibition make explicit the connection between Flechtheim's stolen assets and some of the contemporary private and public collections from which works have been borrowed for this show, the wall texts accompanying each work could make this history more clear.

Yet Wallner's curatorial strategy has paid off in a striking exhibition in which Flechtheim is far more than a phantom. We meet him in the comfortable foyer of the Kolbe Museum in the form of the stark, sensual bust by Rudolf Belling that has become the emblem of the show: expressive profile, mobile eyebrows and robust mouth - lively, decadent and vulnerable.

From this vestibule, I could also see the garden in which four very large columns by Georg Kolbe have been placed. This museum was the home and studio of Kolbe, and this physical and mental re-placement here, and via the museum's skylights and floor-to-ceiling windows facing the same grotto in its main gallery, made for a nice flow of meditation on history as well as formal content.

There is not a single, canonical work as headliner. Rather, in the break from the Academy, there was a search for visual symbols, and through making the labour visible on the surfaces, the works express the sensibilities of inner realities. At the same time, the strand of Modernism that is manifesto and outrage is not at once evident.

Some of the most poignant figures come via France. Edgar Degas's search for form ranged widely through medium, and though this quest was one of the driving forces in his painting, sculpture was not one of his obvious achievements. It was Flechtheim who saw the possibilities in the more than 100 wax models Degas left behind in his Paris studio, discovered after his death. Flechtheim secured the rights to have the models cast in bronze, bringing many to German museums and private collectors. The Kolbe exhibit features two of these small dancers, displayed in vitrines, in poses that call attention to not only the grace but the strength of the female body, which is also the subject, though in a more transcendental guise, of Moissey Kogan.

Yielding to cultural pessimism and rejecting popular faith in material progress, Kogan's response to modernity was to reestablish contact with age-old sources of meaning and vitality, connecting him to the Expressionist painters with whom he worked in Munich before the First 
World War. But it was also in Paris where Flechtheim and Kogan met. The lone Kogan in the exhibition - a serene, three-quarter length classical pale torso - is really the show's key work, effectively symbolizing the sense of death and loss that hovers.

Perhaps the one bit of curatorial humour in the show is another Belling, a large metallic abstraction, assertive and energetic. Positioned to intrude on the conversation between a serene seated woman cloaked in alabaster by Gerhard Marcks and a standing, stretching bronze by Marg Moll, this sinister, dancing flower is the focal point of the Kolbe's main gallery area.

The interesting placement of this sleek entity makes Ernst Barlach's normally monumental works look rugged or like pastiches of pre-Columbian totems, but even to the most inexperienced eye, they still have a presence that places them outside of any temporal or categorical criteria.

If the character of the museum implies an overall professional space of refinement, then anti-formal personal photographs and informational alcoves offer an alternative, suggesting the comfort and chaos of home. In fact, one of the most striking aspects of the exhibition are displays about Flechtheim and his wife, Betty Goldschmidt Flechtheim (who, facing deportation, committed suicide in 1941), and also some of artists who were Flechtheim's clients in their intimate spaces, complete with stacks of toppling books and dogs hugging hearths. One assemblage showcases covers, columns and illustrations from Flechtheim's house organ Der Querschnitt, a less-political, more pop-culture leaning Berlin counterpoint to Herwarth Walden's Der Sturm. The museum's archival impulse extends through a particularly unusual and compelling ode to Renée Sintenis, incorporating tiny, Passbild-sized vernacular photos of the artist and her wire-haired fox terrier, which make a lovely complement, and invites similar close inspection of Sintenis's palm-sized bronzes of foals and dogs.

The mix of tension and influence is perhaps expressed best again by Belling in his 1929 naturalistic study of Max Schmeling, the heavyweight boxing champion of the world - who was also friends with Flechtheim. Sports as an acceptable theme had, since the beginning of the 1900s, already crept into modernist paintings by Max Liebermann and Robert Delaunay. As opposed to Arno Breker, Belling's interest in the physiques of athletes was simply an acknowledgment of a more mediated modern world.

There is not a designated official catalogue for the exhibition, but there is an excellent companion volume of essays, Sprung in den Raum: Skulpturen bei Alfred Flechtheim (in German) which includes substantial chapters about the featured artists, including chapters by Helen Shiner, the Oxford-based art historian compiling the Moissey Kogan catalogue raisonné, and Arie Hartog, director of the Gerhard-Marcks-Haus in Bremen.

Curated by Dr Julia Wallner, Kolbe Museum director.

\section{Reference}

Bowley, Graham. 2016. "Jewish Dealer's Heirs File Suit over Art in Bavarian State Collection.” The New York Times, December 6. https:/www.nytimes.com/2016/12/06/arts/design/jewish-dealers-heirs-file-suit-overart-in-bavarian-state-collection.html. 